\title{
Effect of sodium nitroprusside (SNP) on the germination of Senna macranthera seeds (DC. ex Collad.) H. S. Irwin \& Baneby under salt stress ${ }^{1}$
}

\author{
Aparecida Leonir da Silva ${ }^{2 *}$, Denise Cunha Fernandes dos Santos Dias ${ }^{3}$, Eduardo \\ Euclydes de Lima e Borges ${ }^{4}$, Dimas Mendes Ribeiro², Laércio Junio da Silva ${ }^{3}$
}

\begin{abstract}
Nitric oxide (NO) has been used as stimulating of the germination process for many species. However, there are few studies evaluating the effect of nitric oxide donor in the regulation of seed germination under salt stress, especially for native forest species. The objective was to evaluate the effects of SNP, an NO donor substance, on germination of Senna macranthera seeds under salt stress. The seeds were germinated at different osmotic potentials induced by $\mathrm{NaCl}$ solution $(0.0$, $-0.1,-0.2,-0.3,-0.4$ and $-0.5 \mathrm{MPa})$. To evaluate the effect of the SNP, potentials -0.3 and $-0,4 \mathrm{MPa}$ were selected, applying SNP at different concentrations: 100, 200, 300 and $400 \mu \mathrm{M}$. Germination tests were conducted at $25^{\circ} \mathrm{C}$, with photoperiod of 8 hours. Percentage of radicle protrusion, radicle protrusion speed index, percentage of normal seedlings, shoots and roots length and dry matter were evaluated. Salt stress with $\mathrm{NaCl}$ is harmful to germination of $S$. macranthera seeds. SNP has the potential to recover germination under salt stress, especially in the concentration of $100 \mu \mathrm{M}$.
\end{abstract}

Index terms: "fedegoso", $\mathrm{NaCl}$, nitric oxide, native species.

\section{Efeito do nitroprussiato de sódio (SNP) na germinação de sementes de Senna macranthera (DC. ex Collad.) H. S. Irwin \& Baneby sob estresse salino}

\begin{abstract}
RESUMO - O óxido nítrico $(\mathrm{ON})$ vem se destacando como estimulador do processo de germinação para muitas espécies. Há poucos estudos que avaliam o efeito do doador de óxido nítrico na regulação da germinação de sementes sob estresse salino, principalmente na germinação de espécies florestais nativas. Objetivou-se avaliar os efeitos do nitroprussiato de sódio (SNP), uma substância doadora de ON, na germinação de sementes de Senna macranthera sob estresse salino. As sementes foram colocadas para germinar em diferentes potenciais osmóticos, induzidos por solução de $\mathrm{NaCl}(0,0 ;-0,1 ;-0,2 ;-0,3 ;-0,4$ e -0,5 MPa). Para testar o efeito do SNP, selecionou-se os potenciais de -0,3 e -0,4 MPa, com aplicação de SNP em diferentes concentrações: 100, 200, 300 e $400 \mu \mathrm{M}$. Os ensaios germinativos foram conduzidos em câmara de germinação a $25^{\circ} \mathrm{C}$, com fotoperíodo de 8 horas. Foram avaliados a protrusão radicular, o índice de velocidade de protrusão radicular, a porcentagem de plântulas normais, o comprimento da parte aérea e do sistema radicular, massa seca da parte aérea e do sistema radicular. O estresse salino com $\mathrm{NaCl}$ é prejudicial a germinação de sementes de $S$. macranthera. O SNP tem potencial para promover a recuperação da germinação das sementes sob estresse salino, sendo a concentração de $100 \mu \mathrm{M}$ a mais eficaz.
\end{abstract}

Termos para indexação: fedegoso, $\mathrm{NaCl}$, óxido nítrico, espécie nativa.

\section{Introduction}

Senna macranthera is an arboreal species, belonging to the Fabaceae - Caesalpinioideae family, popularly known as "Fedegoso" (Lorenzi, 2000). The species is widely used in landscaping due to its ornamental characteristics and small

Submitted on 9/2/2015. Accepted for publication on 10/28/2015.

${ }^{2}$ Departamento de Biologia Vegetal, Universidade Federal de Viçosa, 36570-000 - Viçosa, MG, Brasil.

${ }^{3}$ Departamento de Fitotecnia, Universidade Federal de Viçosa, 36570-000 Viçosa, MG, Brasil. size, which is ideal for urban trees. It is a pioneering, fastgrowing species, recommended for use in plantations in degraded areas (Lorenzi, 2000).

Demand for seedlings of native forest species has been growing due to the need of reforestation. Most of these species are propagated by seeds; success in the formation of

${ }^{4}$ Departamento de Engenharia Florestal, Universidade Federal de Viçosa, 36570-000 - Viçosa, MG, Brasil.

*Corresponding author<aparecidaleonir@gmail.com> 
seedlings depends on the knowledge about the regulation of seeds germination and the quality thereof, for each species (Rego et al., 2009).

The seeds are often exposed to various environmental stresses that negatively interfere in germination, vegetative development, plant productivity and, in severe cases, can lead to seedlings death. According to Braga et al. (2009), the time period required for germination is important for the survival of forest species, especially where water availability is limited during certain periods of the year.

Germination is a physiological event that depends on seed quality and environmental conditions such as water supply and oxygen, and temperature and light suitability (Maekawa et al., 2010). Seed hydration is the most important event, because water is the matrix where most biochemical and physiological processes occur and result in primary root protrusion (Moraes et al., 2005). Salt stress affects one of the main processes of the plant life cycle, namely, seeds germination (Cesur and Tabur, 2011; Zheng et al., 2009), leading to a reduced and delayed germination rate (Singh et al., 2012). One of the most widespread methods to determine plants tolerance to salt stress is the observation of germination in saline substrates (Lima and Torres, 2009).

Salinity affects germination, not only due to hindering water absorption, but also to facilitating the entry of toxic amounts of ions in the seeds during imbibition (Simaei et al., 2012). Moreover, salt stress causes changes in seeds physiology due to ionic toxicity, osmotic stress and increased reactive oxygen species (ROS) (Mittler, 2002), leading to gradual lipid peroxidation and antioxidant enzyme inactivation (Tanou et al., 2009). Fan et al. (2013) emphasize the importance of further studies to understand the physiological mechanisms involved on seed germination under salt stress and develop appropriate measures to alleviate the negative effects of salinity on germination.

There are several reports in the literature on the harmful effect of salt stress on seed germination. In seeds of forest species, this effect for species Schizolobium amazonicum (Braga et al., 2008), Enterolobium schomburgkii (Braga et al., 2009), Chorisia speciosa (Fanti and Perez, 2004), Dimorphandra mollis (Masetto et al., 2014), Gliricidia sepium (Farias et al., 2009) and Zizyphus joazeiro (Lima and Torres, 2009) have already been observed.

Among the factors that favor germination under stress conditions, nitric oxide (NO) has stood out as a stimulator of the process in many species. NO is a free radical produced from L-arginine, toxic, inorganic, and colorless gas, with seven nitrogen atoms and eight oxygen atoms, being one of the most important mediators of cellular signaling (Dusse et al., 2003). One of the limiting factors in the studies on the possible actions of NO in plants is the absence of mutants with a differential production of $\mathrm{NO}$, in addition to the lack of mechanisms to perceive and translate the signals induced by this compound (Ederli et al., 2009). Therefore, ON donor and sequestering substances have been widely used in studies to elucidate their functions. The most used reagents as $\mathrm{ON}$ donors are sodium nitroprusside (SNP) and S-Nitroso-Nacetylpenicillamine (SNAP).

Several studies have shown a positive effect of NO on the recovery of seed germination under different types of stress. However, there are few studies that evaluate the effect of NO on seeds germination in salt stress conditions, particularly in native species. It was found in Lupinus luteu seeds that SNP was effective in reversing the negative impact of $\mathrm{NaCl}$ on germination (Kopyra and Gwóźdź', 2003); this reversal was also observed in Cucumis sativus (Fan et al., 2013) and Ocimum basilicum (Saeidnejad et al., 2013) seeds.

The positive effect of NO on the seed germination process is observed in some studies, but there are no reports of the effect of SNP on seed germination of S. macranthera under saline conditions. Given the above, this study has aimed to evaluate the effects of SNP on seed germination of $S$. macranthera under salt stress induced by $\mathrm{NaCl}$.

\section{Material and Methods}

Senna macranthera seeds were collected in 2012 in the Brazilian city of Viçosa, Minas Gerais. The seeds were stored in cold room at $5{ }^{\circ} \mathrm{C}$ and relative humidity of $60 \%$. Before establishing the tests, all seeds were mechanically scarified with sandpaper number 100 on the opposite side to the hilum and then they were treated with fungicide Captan at $0.2 \%$.

Experiment I - Evaluation of root protrusion and seed germination of S. macranthera under salt stress conditions

The seeds were germinated in saline stress conditions, obtained by using saline solution of sodium chloride ( $\mathrm{NaCl}, \mathrm{P} . \mathrm{M}$. 58.44). The following osmotic potentials were tested: $-0.1 ;-0.2$; $-0.3 ;-0.4$ and $-0.5 \mathrm{MPa}$. The salt concentrations for each osmotic potential were obtained based on the equation by J. H. van't Hoff, cited by Salisbury and Ross (1992): $\psi_{\text {os }}=-$ RTC, where:

$\psi_{\mathrm{os}}=$ osmotic potential (atm);

$\mathrm{R}=$ general ideal gas constant $\left(0.082 \mathrm{~atm} .1 . \mathrm{mol}^{-10} \cdot \mathrm{k}^{-1}\right)$;

$\mathrm{T}=$ temperature $\left({ }^{\circ} \mathrm{K}\right)$; and

$\mathrm{C}=$ concentration $(\mathrm{mol} / 1)($ No. of moles $/ \mathrm{l})$.

For the germination test, four replications of 50 seeds 
were placed on paper towel rolls moistened with water (control) or saline solution at a ratio of 2.5 times the dry paper weight. Subsequently, the rolls were placed in plastic bags. The germination test was conducted in a germinator at $25^{\circ} \mathrm{C}$, with a photoperiod of 8 hours.

The numbers of seeds with protruded primary radicle and germination percentage (normal seedlings) were daily assessed. Seeds whose primary root had at least $2 \mathrm{~mm}$ in length were considered protruded. The percentage of normal seedlings was detemined following the criteria established by Rules for Seed Testing (Brasil, 2009). On the seventh day after sowing, the percentage of root protrusion and germination was calculated. With daily data, radicle protrusion speed index (RPSI) was calculated.

At the end of the germination test, shoot length (CPA) and root system length (RSL) of seedlings were evaluated, with the aid of a digital caliper. The results were expressed in millimeters per seedling. Dry matter of shoot (DMS) and root dry matter (RDM) were determined by the oven method with forced air circulation, set at $70{ }^{\circ} \mathrm{C}$, where the seedlings remained until constant weight.

Experiment II - Nitric oxide effect on root protrusion and germination of S. macranthera seeds under salt stress conditions

The seeds were germinated under salt stress conditions in osmotic potentials -0.3 and $-0.4 \mathrm{MPa}$ of $\mathrm{NaCl}$ (defined according to the results of the previous experiment). For each potential, sodium nitroprusside solution (SNP) were applied in concentrations of 100, 200, 300 and $400 \mu \mathrm{M}$.

For the germination test, four replications of 50 seeds were germinated in accordance with the procedures adopted in the previous experiment. The substrate was moistened with a mixture of $\mathrm{NaCl}$ and SNP solutions, in the proportion of 2.5 times the weight of the dry paper. Percentage of primary root protrusion, RPSI and germination percentage were determined.

\section{Statistical analysis}

Experiment I was conducted in a completely randomized design with four replications. The data were submitted to analysis of variance (ANOVA) and expressed as mean \pm standard deviation. Experiment II was conducted in a completely randomized design with four replications in a 2 x 4 factorial arrangement, i.e., two osmotic potentials ( -0.3 and -0.4 MPa) and four concentrations of SNP (100, 200, 300 and $400 \mu \mathrm{M})$. Root protrusion data were transformed by the arcsine function and then they were subjected to analysis of variance. The results obtained for the salt concentrations were expressed as mean \pm standard deviation.

\section{Results and Discussion}

S. macranthera seeds present integument hardness, which corresponds to the characteristic primary dormancy mechanism of the species (Lorenzi, 2000). In this study, the control treatment seeds (water) presented high root protrusion $(87 \%)$, showing the efficiency of the mechanical scarification procedure indicated by Lemos Filho et al. (1997) in overcoming the species dormancy.

There was a gradual decrease in root protrusion and seed vigor by reducing the osmotic potential (Figure 1), where the seeds protrusion percentage under potential $0.0 \mathrm{MPa}$ was $87 \%$ to $36 \%$ in potential $-0.5 \mathrm{MPa}$. A more drastic effect of salinity was observed, with a significant reduction in radicle protrusion speed index, germination, shoot length and root system length with increased salt stress (Figures 1B, 1C, 1D and $1 \mathrm{E}$ ). Although some seeds still emit radicle, there was no formation of seedling in saline potentials -0.4 and -0.5 $\mathrm{MPa}$. There was a slight increase in the aerial part dry matter in potentials -0.3 and $-0.4 \mathrm{MPa}$ and root remained stable at concentrations of $-0.1 ;-0.2$ and $-0.3 \mathrm{MPa}$ in relation to control (Figures $1 \mathrm{~F}$ and $1 \mathrm{G}$ ).

In seeds of other forest species, harmful effect of salt stress has also been found, such as for Schizolobium amazonicum (Braga et al., 2008) and Enterolobium schomburgkii (Braga et al., 2009), especially in reducing germination percentage, with significant decreases from potentials at $-0.2 \mathrm{MPa}$ in the solution of $\mathrm{NaCl}$. However, in studies conducted by Fanti and Perez (2004) significant decreases in germination percentage to the osmotic potential of $-0.4 \mathrm{MPa}$ in Chorisia speciosa seeds were not observed, but from -0.6 MPa significant reductions in viability were recorded. For Gliricidia sepium (Farias et al., 2009) germination was significantly affected only in osmotic potentials above -1.0 MPa. In Zizyphus joazeiro all salt concentrations used $(-0.3 ;-0.6$ and $-0.9 \mathrm{MPa})$ significantly decreased germination (Lima and Torres, 2009).

According to the results found in this study, $S$. macranthera seeds showed greater decrease in root protrusion from osmotic potential $-0.4 \mathrm{MPa}$; for other species, this potential also proved harmful, such as for Senna occidentalis (Norsworthy and Oliveira, 2005), Senna obtusifolia (Pereira et al., 2014) and Dimorphandra mollis (Masetto et al., 2014).

It is noticed that the seeds of different species support different osmotic salt stresses on germination, and the seedlings are the most sensitive. One of the factors responsible for the reduction in germination may have been an excess of ions $\mathrm{Na}^{+}$and $\mathrm{Cl}^{-}$, since they cause decreased protoplasmic swelling (Ferreira and Borghetti, 2004). Another factor may have been the excess of soluble salts, resulting in reduced

Journal of Seed Science, v.37, n.4, p.236-243, 2015 
water potential, i.e., the water absorption capacity of the seeds is reduced. This reduction of water potential and the salts toxic effects initially interfere with the process of water uptake by seeds, influencing vigor, affecting speed and thus the germination time of these seeds in non-toxic levels of salinity (Cavalcante and Perez, 1995).
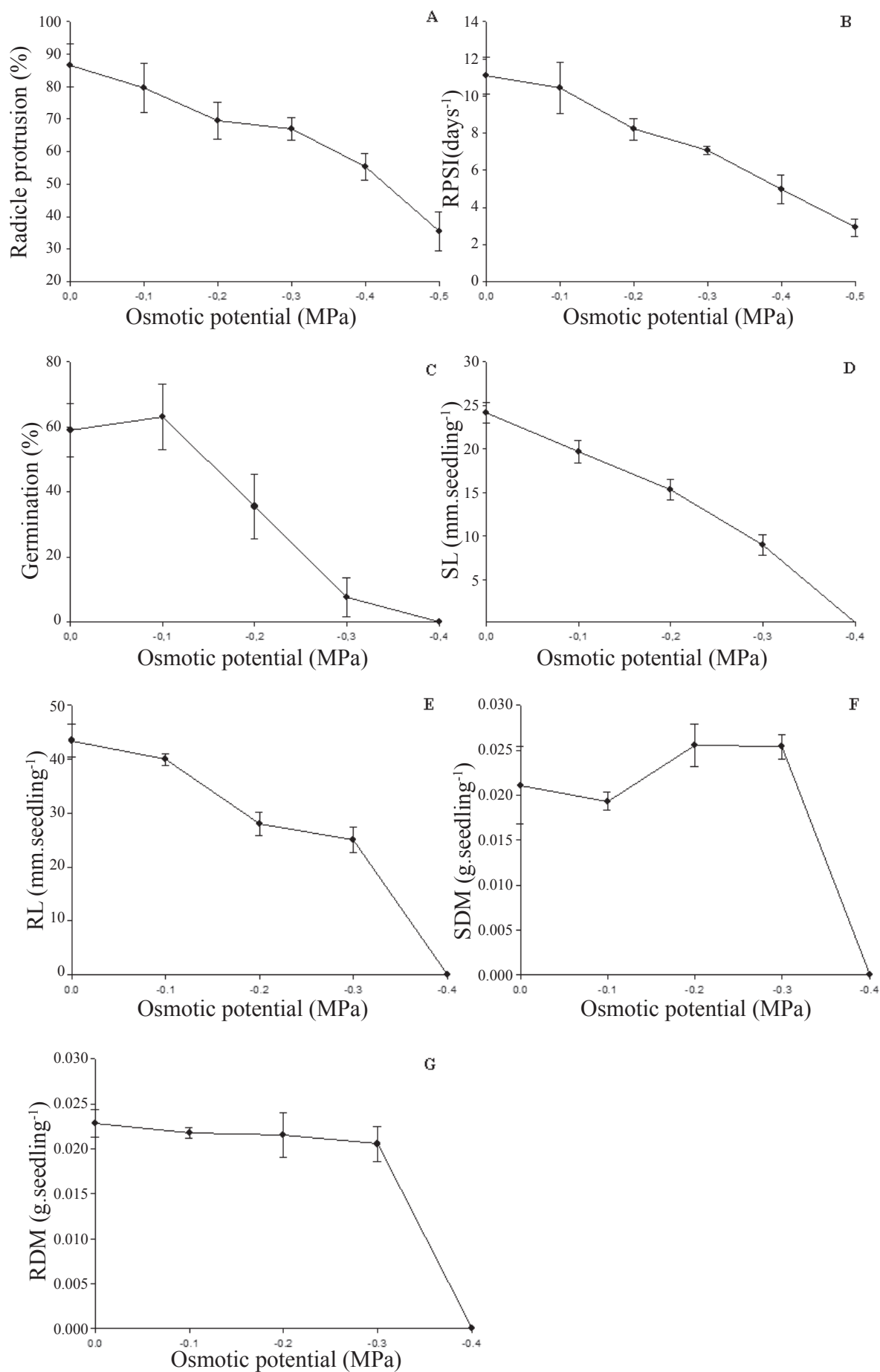

Figure 1. A: Percentage of root protrusion, B: root protrusion speed index (RPSI), C: percentage of germination, D: shoot length (SL), E: root length (RL), F: dry matter of shoot (DMS) and G: root dry matter (RDM), of Senna macranthera seeds, scarified and germinated in different osmotic potentials with $\mathrm{NaCl}(0.0 ;-0.1 ;-0.2 ;-0.3 ;-0.4$ and $-0.5 \mathrm{MPa})$ at $25{ }^{\circ} \mathrm{C}$. 
Bewley et al. (2013) have pointed out that the seeds moderate resistance to salt stress is useful when trying to use saline soils in dry regions, since $6 \%$ of terrestrial continents are made up of saline soils. Knowledge of species able to withstand these conditions can aid in the proper recommendation of species for planting, especially for native species, for which there is limited information (Rego et al., 2011).

Species tolerant to salt stress are classified as halophytes or glycophytes due to their tolerance to salt stress, both respond similarly to salt stress, and the percentage and germination rate are inversely proportional to increased salinity, varying only the salt tolerance limit (Jeller and Perez, 2001). Halophyte species are highly tolerant, germinating in the environment with up to $8 \%$ of $\mathrm{NaCl}$ (Ungar, 1978), and the ones that are little tolerant have their germination inhibited at $1.5 \%$ of $\mathrm{NaCl}$. Most glycophytes do not germinate in medium with concentrations higher than $1.5 \%$ of $\mathrm{NaCl}$. In this study, S. macranthera may be included among the little salt-tolerant glycophytes because it does not have a high tolerance limit (up to -0.4 MPa). Similar results were found for Senna spectabilis, also included among the little salt-tolerant glycophytes, with a limit of -1.6 MPa (Jeller and Perez, 2001).

From the results of radicle protrusion percentage obtained in the first assay (Figure 1A), two salt concentrations were selected, which caused moderate stress, with root protrusion around $50 \%$ to evaluate SNP effect on the recovery of the seeds physiological potential. The selected concentrations were -0.3 and $-0.4 \mathrm{MPa}$, due to promoting moderate stress levels in radicle protrusion of $S$. macranthera seeds (67 and $55 \%$, respectively).

Thus, there was an increase in root protrusion and shoot length of the seedlings, and decrease in radicle protrusion speed index for all concentrations of SNP tested (100, 200, 300 and $400 \mu \mathrm{M}$ ) in the potential of $-0.3 \mathrm{MPa}$ (Figures $2 \mathrm{~A}$ and $\mathrm{B})$. There was an increase of $18 \%$ in root protrusion and of $225 \%$ in germination, compared to the control (without application of SNP) at a concentration of $100 \mu \mathrm{M}$ of SNP (Figure 2). Although there is a small reduction in dry matter of shoot and root system compared to the control, this was not significant (Figures $2 \mathrm{~F}$ and $\mathrm{G}$ ).

There was an increase in seeds root protrusion under salt stress $-0.4 \mathrm{MPa}$ with the application of SNP at concentrations of $100(15 \%), 200(10 \%)$ and $300 \mu \mathrm{M}(17 \%)$, compared to pure salt stress (Figure 3 ). The radicle protrusion speed index decreased in all concentrations $(100,200,300$ and 400 $\mu \mathrm{M})$ of SNP, compared to the control (-0.4 MPa). Thus, it is possible to observe the limitation of SNP effect in reversing the inhibitory effect of salt stress in seedling production.

There are no reports in the literature about the germination behavior of native forest species with nitric oxide donor application in the reversal of salt stress. However, in Lupinus luteus seeds from the Fabaceae family, SNP also proved effective in reversing the decline of germination caused by $\mathrm{NaCl}$ (Kopyra and Gwóźdź', 2003). For Cucumis sativus, the recovery of salt stresses was more effective at the concentration of $50 \mu \mathrm{M}$ of SNP; however, there was a decrease in germination at the highest concentration of SNP (400 $\mu \mathrm{M})$ (Fan et al., 2013). In Triticum aestivum seeds there was a significant increase in germination after seven days of seed germination with SNP under salt stress with $\mathrm{NaCl}$ (Zheng et al., 2009).

However, in Ocimum basilicum seeds there was no increase in seed germination with nitric oxide donor, probably because it relieves salt stress through changes in physiological properties and the antioxidant system (Saeidnejad et al., 2013).

According to Correa-Aragunde et al. (2004) and Lombardo et al. (2006), nitric oxide is involved in the regulation of root morphology. Correa-Aragunde et al. (2004) have found that nitric oxide affects the growth of Lycopersicon esculentum roots in a dose-dependent manner, wherein SNP at low concentrations stimulates root growth, while high concentrations have an inhibitory effect on growth.

In general, $S$. macranthera seeds are sensitive to salt stress induced by $\mathrm{NaCl}$, with reduction of root protrusion, germination and seed vigor, especially in osmotic potential below -0.4 MPa. SNP was efficient in the recovery of the physiological potential of $S$. macranthera seeds at the concentration of $100 \mu \mathrm{M}$. 

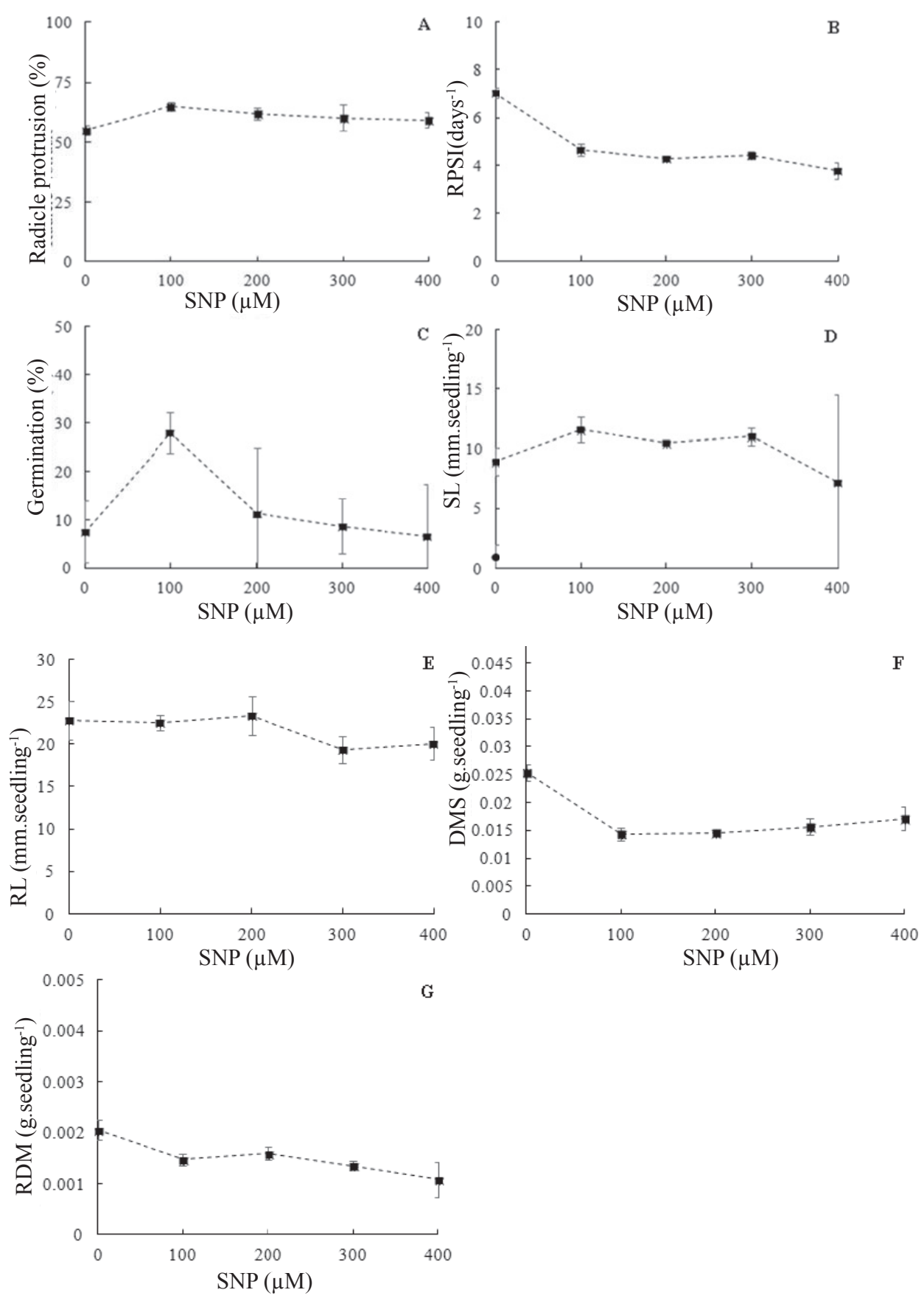

Figure 2. A: Percentage of root protrusion, B: radicle protrusion speed index (RPSI), C: percentage of germination, D: shoot length (SL), E: root length (RL), F: dry matter of shoot (DMS) and G: root dry matter (RDM), of Senna macranthera seeds, scarified and germinated in osmotic potential with $\mathrm{NaCl}-0.3 \mathrm{MPa}$ together with different concentrations of SNP $(100,200,300$ and $400 \mu \mathrm{M})$ at $25^{\circ} \mathrm{C}$. 

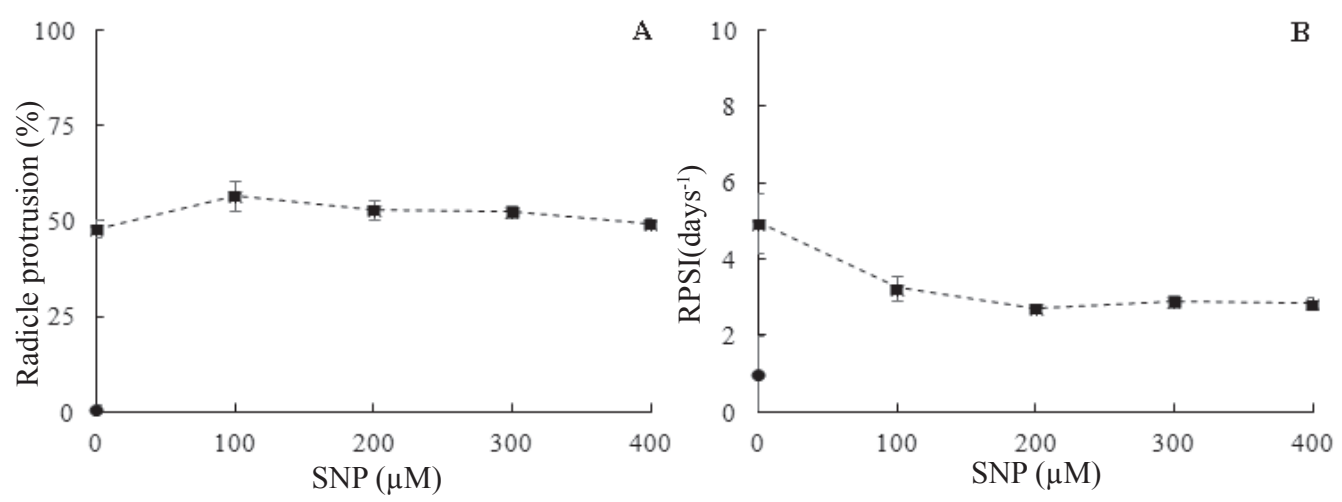

Figure 3. A: Percentage of root protrusion, B: radicle protrusion speed index (RPSI) of Senna macranthera seeds, scarified and germinated in osmotic potential with $\mathrm{NaCl}-0.4 \mathrm{MPa}$ together with concentrations of SNP (100, 200, 300 and $400 \mu \mathrm{M})$ at $25^{\circ} \mathrm{C}$.

\section{Conclusions}

Salt stress is harmful to germination of $S$. macranthera seeds.

SNP has the potential to promote germination recovery under salt stress more effectively when applied at a concentration of $100 \mu \mathrm{M}$.

\section{Acknowledgments}

We thank CAPES (Coordenação de Aperfeiçoamento de Pessoal de Nível Superior) for supporting and granting a scholarship.

\section{References}

BEWLEY, J.D.; BRADFORD, K.J.; HILHORST, H.W.M.; NONOGAKI, H. Seeds: Physiology of development, germination and dormancy. New York: Plenum, 2013. 392p.

BRAGA, L.F.; SOUSA, M.P.; CESARO, A.S.; LIMA, G.P.P.; GONÇALVES, A.N. Germinação de sementes de pinho-cuiabano sob deficiência hídrica com diferentes agentes osmóticos. Scientia Forestalis, v.36, n.78, p.157-163, 2008. http://www.ipef.br/publicacoes/scientia/nr78/cap08.pdf

BRAGA, L.F.; SOUSA, M.P.; ALMEIDA, T.A. Germinação de sementes de Enterolobium schomburgkii (Benth.) Benth. submetidas a estresse salino e aplicação de poliamina. Revista Brasileira de Plantas Medicinais, v.11， n.1， p.63-70, 2009. http://www.scielo.br/scielo.php?script=sci arttext\&pid=S1516-05722009000100011

BRASIL. Ministério da Agricultura, Pecuária e Abastecimento. Regras para análise de sementes. Ministério da Agricultura, Pecuária e Abastecimento. Secretaria de Defesa Agropecuária. Brasília: MAPA/ACS, 2009. 395p. http:// www.agricultura.gov.br/arq_editor/file/2946_regras_analise_sementes.pdf

CAVALCANTE, A.M.B.; PEREZ, S.C.J.G.A. Efeitos dos estresses hídrico e salino sobre a germinação de sementes de Leucaena leucocephala (Lam.) de Witt. Pesquisa Agropecuária Brasileira, v.30, p.281-289, 1995. http://www. alice.cnptia.embrapa.br/bitstream/doc/104187/1/pab17fev95.pdf
CESUR, A.; TABUR, S. Chromotoxic effects of exogenous hydrogen peroxide $\left(\mathrm{H}_{2} \mathrm{O}_{2}\right)$ in barley seeds exposed to salt stress. Acta Physiology Plant, v.33, p.705-709, 2011. http://link.springer.com/article/10.1007\%2Fs11738010-0594-7\#page-1

CORREA-ARAGUNDE, N.; GRAZIANO, M.; LAMATTINA, L. Nitric oxide plays a central role in determining lateral root development in tomato. Planta, v.218, p.900-905, 2004. http://www.ncbi.nlm.nih.gov/ pubmed/14716561

DUSSE, L.M.S.; VIEIRA, L.M.; CARVALHO, M.G. Revisão sobre óxido nítrico. Jornal de Patologia e Medicina Laboratorial, v.39, n.4, p.343-350, 2003. http:// www.scielo.br/scielo.php?script=sci_arttext\&pid=S1676-24442003000400012

EDERLI, L.; REALE, L.; MADEO, L.; FERRANTI, F.; GEHRING, C.; FORNACIARI, M.; ROMANO, B.; PASQUALINI, S. NO release by nitric oxide donors in vitro and in planta. Plant Physiology and Biochemistry, v.47, p.42-48, 2009. http://www.ncbi.nlm.nih.gov/pubmed/18990582

FAN, H.F.; DU, C.X.; DING, L.; XU, Y.L. Effects of nitric oxide on the germination of cucumber seeds and antioxidant enzymes under salinity stress. Acta Physiology Plant, v.35, p.2707-2719, 2013. http:// download.springer.com/static/pdf/171/art\%253 A $10.1007 \% 252$ Fs 11738-013-1303-0.pdf?originUrl=http $\% 3 \mathrm{~A} \% 2 \mathrm{~F} \% 2 \mathrm{Flink}$.springer. com $\% 2$ Farticle $\% 2 \mathrm{~F} 10.1007 \% 2 \mathrm{Fs} 11738-013-1303-0 \&$ token $2=\exp =1450$ 179762 acl $=\% 2 \mathrm{Fstatic} \% 2 \mathrm{Fpdf} \% 2 \mathrm{~F} 171 \% 2 \mathrm{Fart} \% 25253 \mathrm{~A} 10.1007 \% 25252$ Fs11738-013-1303-0.pdf\%3ForiginUrl\%3Dhttp\%253A\%252F\%252Flink. springer.com $\% 252$ Farticle $\% 252 \mathrm{~F} 10.1007 \% 252 \mathrm{Fs} 11738-013-1303-0 * \sim \mathrm{hmac}=$ ac97ec09bae92db87ec4bcff025c51c74688767d1196dee4060882822baded03

FANTI, S.C.; PEREZ, S.C.J.G.A. Processo germinativo de sementes de paineira sob estresses hídrico e salino. Pesquisa Agropecuária Brasileira, v.39, n.9, p.903-909, 2004. http://www.scielo.br/scielo.php?pid=s0100204x2004000900010\&script=sci_arttext

FARIAS, S.G.G.; FREIRE, A.L.O.; SANTOS, D.R.; BAKKE, I.A.; SILVA, R.B. Efeitos dos estresses hídrico e salino na germinação de sementes de Gliricidia [Gliricidia sepium (JACQ.) STEUD.]. Revista Caatinga, v.22, n.4, p.152-157, 2009. http://periodicos.ufersa.edu.br/revistas/index.php/sistema/ article/view/1329

FERREIRA, A.G.; BORGUETTI, F. Germinação: do básico ao aplicado. Porto Alegre: Artmed, 2004. 323p 
JELLER, H.; PEREZ, S.C.J.G.A. Efeitos dos estresses hídrico e salino e da ação de giberelina em sementes de Senna spectabilis. Ciência Florestal, v.11, n.1, p.93-104, 2001. http://coral.ufsm.br/cienciaflorestal/artigos/v11n1/ art9v11n1.pdf

KOPYRA, M.; GWÓŹDŹ', E.A. Nitric oxide stimulates seed germination and counteracts the inhibitory effect of heavy metals and salinity on root growth of Lupinus luteus. Plant Physiology Biochemistry, v.41, p. 1011-1017, 2003. http://www.sciencedirect.com/science/article/pii/S098194280300175X

LEMOS FILHO, J.P.; GUERRA, S.T.; LOVATO, M.B.; SCOTTI, M.R.M.M.L. Germinação de sementes de Senna macranthera, Senna multijuga e Stryphnodendron polyphyllum. Pesquisa Agropecuária Brasileira, v.32, n.4, p.357-361, 1997. http://seer.sct.embrapa.br/index.php/pab/article/view/4653

LIMA, B.G.; TORRES, S.B. Estresses hídrico e salino na germinação de sementes de Zizyphus joazeiro Mart. (Rhamnaceae). Revista Caatinga, v.22, n.4, p.93-99, 2009. http://www.redalyc.org/pdf/2371/237117843016.pdf

LOMBARDO, M.C.; GRAZIANO, M.; POLACCO, J.C.; LAMATTINA, L. Nitric oxide functions as a positive regulator of root hair development. Plant Signaling \& Behavior, v.1, p.28-33, 2006. http://www.ncbi.nlm.nih. gov/pubmed/19521473

LORENZI, H. Árvores Brasileiras: Manual de Identificação e Cultivo de Plantas Arbóreas Nativas do Brasil. 3. ed. Nova Odessa, SP: Instituto Plantarum de Estudos da Flora Ltda, 2000. 352p.

MAEKAWA, L.; ALBUQUERQUE, M.C.F.; COELHO, M.F.B. Germinação de sementes de Aristolochia esperanzae O. Kuntze em diferentes temperaturas e condições de luminosidade. Revista Brasileira de Plantas Medicinais, v.12, n.1, p.23-30, 2010. http://www.scielo.br/pdf/rbpm/v12n1/v12n1a05.pdf

MASETTO, T.E.; SCALON, S.P.Q.; REZENDE, R.K.S.; OBA, G.C.; GAMBATTI, M.; PATRÍCIO, V.S. Germinação de sementes de Dimorphandra mollis Benth.: efeito de salinidade e condicionamento osmótico. Revista Brasileira de Biociências, v. 12, n.3, p.127-131, 2014. http://www.ufrgs.br/ seerbio/ojs/index.php/rbb/article/view/2736

MITTLER, R. Oxidative stress, antioxidants and stress tolerance. Trends in Plant Science, v.7, n. 9, p.405-410, 2002. http://www.sciencedirect.com/ science/article/pii/S1360138502023129

MORAES, G.A.F.; MENEZES, N.L.; PASQUALLI, L.L. Bean seed performance under different osmotic potentials. Ciência Rural, v.35 n.4, p.776-780, 2005. http://www.scielo.br/scielo.php?script=sci arttext\&pid=S0103-84782005000400004

NORSWORTHY, J.K.; OLIVEIRA, M.J. Coffee senna (Cassia occidentalis) germination and emergence is affected by environmental factors and seedling depth. Weed Science, v.53, n.5, p. 657-662, 2005. http://www.jstor.org/ stable/4047034?seq=1\#page scan tab contents

PEREIRA, M.R.R.; MARTINS, C.C.; MARTINS, D.; SILVA, R.J.N. Estresse hídrico induzido por soluções de $\mathrm{PEG}$ e de $\mathrm{NaCl}$ na germinação de sementes de nabiça e fedegoso. Bioscience Journal, v.30, n. 3, p. 687-696, 2014. http:// www.seer.ufu.br/index.php/biosciencejournal/article/view/18049
REGO, S.S.; NOGUEIRA, A.C.; KUNIYOSHI, Y.S.; SANTOS, A.F. Germinação de sementes de Blepharocalyx salicifolius (H.B.K.) Berg. em diferentes substratos e condições de temperaturas, luz e umidade. Revista Brasileira de Sementes, v. 31, n.2, p. 212-220, 2009. http://www.scielo.br/ scielo.php?script=sci_arttext\&pid=S0101-31222009000200025

REGO, S.S.; FERREIRA, M.M.; NOGUEIRA, A.C.; GROSSI, F.; SOUSA R.K.; BRONDANI, G.E.; ARAUJO, M.A.; SILVA, A.L.L. Estresse hídrico e salino na germinação de sementes de Anadenanthera colubrina (Veloso) Brenan. Journal of Biotechnology and Biodiversity, v.2, n.4, p.37-42, 2011. http://revista.uft.edu.br/index.php/JBB/article/view/212/146

SAEIDNEJAD, A.H.; PASANDI-POUR, A.; PAKGOHAR, N.; FARAHBAKHSH, H. Effects of exogenous nitric oxide on germination and physiological properties of basil under salinity stress. Journal of Medicinal Plants and By-products, v.1, p.103-113, 2013. http://www.academia edu/9493044/Effects of Exogenous Nitric Oxide on Germination and Physiological_Properties_of_Basil_under_Salinity_Stress

SALISBURY, F.B.; ROSS, C.W. Plant physiology. 4.ed. Belmont: Wadsworth Publishing Company, 1992. 682p.

SIMAEI, M.; KHAVARI-NEJAD, R.A.; BERNARD, F. Exogenous application of salicylic acid and nitric oxide on the ionic contents and enzymatic activities in NaCl-stressed soybean plants. American Journal of Plant Sciences, v.3, n.10, p.1495-1503, 2012. http://www.scirp.org/journal/ PaperInformation.aspx?PaperID $=24169$

SINGH, J.; SASTRY, E.V.D.; SINGH, V. Effect of salinity on tomato (Lycopersicon esculentum Mill.) during seed germination stage. Physiology Molecular Biology Plants, v.18, n.1, p.45-50, 2012. http://www.ncbi.nlm. nih.gov/pmc/articles/PMC3550529/

TANOU, G.; MOLASSIOTIS, A.; DIAMANTIDIS, G. Induction of reactive oxygen species and necrotic death-like destruction in strawberry leaves by salinity. Environmental and Experimental Botany, v.65, n.2-3, p.270-281, 2009. http://www.sciencedirect.com/science/article/pii/S009884720800107X

UNGAR, I.A. Halophyte seed germination. Botany Review, v.44, p.233-264, 1978. http://www.jstor.org/stable/pdf/4353933.pdf?acceptTC=true

ZHENG, C.; JIANG, D.; LIU, F.; DAI, T.; LIU, W.; JING, Q.; CAO, W. Exogenous nitric oxide improves seed germination in wheat against mitochondrial oxidative damage induced by high salinity. Environmental and Experimental Botany, v.67, p.222-227, 2009. http://www.researchgate. net/publication/260163276_Exogenous_nitric_oxide_improves_seed germination in wheat against mitochondrial oxidative damage induced by_high_salinity._Environ_Exp_Bot 